\title{
An approach to classifying occupational exposures to endocrine disrupting chemicals by sex hormone function using an expert judgment process
}

DOI:

10.1038/s41370-020-0253-z

\section{Document Version \\ Accepted author manuscript}

Link to publication record in Manchester Research Explorer

Citation for published version (APA):

Prichystalova, R., Caron-Beaudoin, E., Richardson, L., Dirkx, E., Amadou, A., Zavodna, T., Cihak, R., Cogliano, V., Hynes, J., Pelland-St-Pierre, L., Verner, M. A., van Tongeren, M., \& Ho, V. (2020). An approach to classifying occupational exposures to endocrine disrupting chemicals by sex hormone function using an expert judgment process. Journal of Exposure Science and Environmental Epidemiology. https://doi.org/10.1038/s41370-020-0253Z

Published in:

Journal of Exposure Science and Environmental Epidemiology

\section{Citing this paper}

Please note that where the full-text provided on Manchester Research Explorer is the Author Accepted Manuscript or Proof version this may differ from the final Published version. If citing, it is advised that you check and use the publisher's definitive version.

\section{General rights}

Copyright and moral rights for the publications made accessible in the Research Explorer are retained by the authors and/or other copyright owners and it is a condition of accessing publications that users recognise and abide by the legal requirements associated with these rights.

\section{Takedown policy}

If you believe that this document breaches copyright please refer to the University of Manchester's Takedown Procedures [http://man.ac.uk/04Y6Bo] or contact uml.scholarlycommunications@manchester.ac.uk providing relevant details, so we can investigate your claim.

\section{OPEN ACCESS}


This manuscript was written in accordance with the instructions for authors provided by the Journal of Exposure Science \& Environmental Epidemiology, a peer-reviewed journal.

Title:

An approach to classifying occupational exposures to endocrine disrupting chemicals by sex hormone function using an expert judgement process

Authors:

R. Prichystalova ${ }^{1}$, E. Caron-Beaudoin ${ }^{2}$, L. Richardson ${ }^{3}$, Dirkx E., A. Amadou ${ }^{5}$ T. Zavodna $^{6}$, R. Cihak ${ }^{7}$, V. Cogliano ${ }^{8}$, J. Hynes ${ }^{9}$, L. Pelland-St-Pierre ${ }^{10}$, M.A. Verner ${ }^{11,12}$, M. van Tongeren ${ }^{13}, \mathrm{~V} . \mathrm{Ho}^{14,15}$

\section{Affiliations}

1. Faculty of Safety Engineering, Technical University of Ostrava, Ostrava, Czech Republic. Email: radka.prichystalova@vsb.cz

2. Department of Occupational and Environmental Health, Université de Montréal, Montréal, Québec, Canada. Email : elyse.caron-beaudoin@umontreal.ca

3. Centre de recherche du CHUM (CRCHUM), Montréal, Québec, Canada. Email : richardsonlesley4@gmail.com

4. Centre de recherche du CHUM (CRCHUM), Montréal, Québec, Canada. Email : evadirkx@hotmail.com

5. Département Prévention Cancer Environnement, Centre Léon Bérard ; Inserm UA 08 Radiations : Défense, Santé, Environnement, France Lyon, France. Email : Amina.amadou@1yon.unicancer.fr

6. Institute of Experimental Medicine of the CAS, Prague, Czech Republic. Email: tana.brzicova@biomed.cas.cz

7. Výzkumný ústav organických syntéz a.s., Centre for Ecology, Toxicology nad Analytics, Rybitví, Czech Republic. Email: rostislav.cihak@vuos.com

8. Integrated Risk Information System, US Environmental Protection Agency, Washington, D.C., USA. Email: cogliano.vincent@epa.gov

9. JH Tox Consulting, Maastricht, Netherlands. Email: jarlath@jhtox.com

10. Department of Social and Preventive Medicine, Université de Montréal, Montréal, Québec, Canada. Email: laura.pelland-st-pierre@umontreal.ca

11. Department of Occupational and Environmental Health, Université de Montréal, Montréal, Québec, Canada. Email : marc-andre.verner.1@umontreal.ca

12. Center for Public Health Research, Montreal, Quebec. Email: marcandre.verner.1@umontreal.ca

13. Faculty of Science and Engineering, Division of Population Health, Health Services Research \& Primary Care, University of Manchester, Manchester, United Kingdomm Email: Martie.J.Van-Tongeren@manchester.ac.uk

14. Department of Social and Preventive Medicine, Université de Montréal, Montréal, Québec, Canada. Email: Vikki.ho@umontreal.ca

15. Centre de recherche du CHUM (CRCHUM), Montréal, Québec, Canada. Email : Vikki.ho@umontreal.ca

Manuscript Word Count: 4,200

Abstract Word Count: 200 
51 Correspondence to:

52 Dr. Vikki Ho

53 Université de Montréal Hospital Research Centre (CRCHUM),

54850 Saint-Denis Street, $3^{\text {rd }}$ Floor, S03-424

55 Montreal, Quebec H2X 0A9, Canada

56 E-mail: vikki.ho@umontreal.ca

57 Tel: $514-890-8000$ ext. 31522

58 Fax: 514-412-7018

59

60

61

62

63

64

65

66

67

68

69

70

71

72

73

74

75

76

77

78

79 


\section{Abstract}

Endocrine disrupting chemicals (EDCs) are exogenous substances that interfere with the endocrine system and cause adverse effects. We aimed to classify the effects of 24 known EDCs, prevalent in certain occupations, according to four modes of action (estrogenic, antiestrogenic, androgenic, and/or anti-androgenic).

A literature search, stratified into four types of literature was conducted (namely: national and international agency reports; review articles; primary studies; ToxCast ${ }^{\mathrm{TM}}$ ). The state of the evidence of each EDC on sex hormone function was summarized and reviewed by an expert panel. For each mode of action, the experts evaluated the likelihood of endocrine disruption in five categories: "No", “Unlikely", "Possibly", "Probably”, and; "Yes”. sex hormone function (anti-androgenic: lead, arsenic, butylbenzyl phthalate, dibutyl phthalate, dicyclohexyl phthalate; estrogenic: nonylphenol, bisphenol A). Ten agents were categorised as "Probable," or having probable evidence (anti-androgenic: bis(2-ethylhexyl)phthalate, nonylphenol, toluene, bisphenol A diisononyl phthalate; androgenic: cadmium, and; estrogenic: copper, cadmium). Two agents (arsenic, polychlorinated biphenyls) had opposing conclusions supporting both "probably" estrogenic and anti-estrogenic effects.

This synthesis will allow researchers to evaluate the health effects of selected EDCs with an added level of precision related to the mode of action.

Keywords: endocrine disruptor, estrogenic, anti-estrogenic, androgenic, anti-androgenic, occupational exposures 
Public concern about the impact of endocrine disrupting chemicals (EDCs) on both humans and the environment is growing steadily. EDCs are exogenous substances that cause adverse health effects through interference with the endocrine system; exposure occurs through occupational, dietary and environmental sources, with food being the major route of exposure

108 for many EDCs $(1,2)$. However, a comparison of reported biomarker levels of selected EDCs

109 revealed that concentrations of these chemicals are between 9 to 45 times higher in 110 occupationally-exposed workers than in the general population (1, 3-7), making this an 111 important and more easily definable target population for study.

112 There is growing evidence that EDCs may affect fertility (8-11) and the progression of 113 some diseases like obesity, endometriosis and some cancers $(8,12,13)$. The disruption of sex 114 hormone homeostasis (14) has been associated with the risk of sex-specific cancers, including: 115 breast and prostate cancers $(15,16)$, and possibly endometrial and ovarian cancers $(17,18)$. The 116 incidence of colorectal cancer differs by sex (19), and accumulating epidemiologic evidence 117 shows that exposure to certain female sex hormones is associated with a lower risk of colorectal 118 cancer (20-23). The main mechanisms of action through which EDCs may disrupt the endocrine system have been previously detailed by Cambarnous (24); they include: 1) inhibiting and/or

121 mimicking the effect of hormones; 2) disrupting the production, metabolism and transport of

122 hormones and; 3) disrupting the production of hormone receptors (25). Pertinent to sex 123 hormones, these effects can be further characterised as: estrogenic (promotes the biosynthesis 124 of estrogens or mimics the physiologic activity of estrogens) (26), anti-estrogenic (inhibits the 125 biosynthesis or physiologic activity or biological effects of estrogens)(27), androgenic 126 (promotes the biosynthesis of androgens or mimic the physiologic activity of androgens) (28) 127 and/or anti-androgenic (inhibits the biosynthesis or physiologic activity or biological effects of 
androgens) (29).

Several researchers have suggested a possible cumulative effect of exposure to multiple EDCs (30-35). Evaluation of these combined effects will be greatly enhanced by taking into account these different modes of action in the assessment of health risks. A consensus statement by La Merrill et al.(36) is one of the most notable recent endeavours to address this issue. A key characteristics framework was developed to search, organize and evaluate mechanistic evidence to support the identification of EDCs. This framework was applied to bisphenol A, diethylstilbestrol and perchlorate and helps to integrate data across a vast literature of mechanistic studies to help identify EDC hazards. Other endeavors, have been more directed and specific; Bonde et al. (37) conducted a systematic review and meta-analysis to systematically synthesize published data on the risk of cryptorchidism, hypospadias, low sperm count and testicular cancer following in utero or infant exposure to suspected EDCs.

Within the context of an epidemiological study currently being conducted to assess occupational exposure to EDCs and colorectal cancer risk within a large Canadian prospective cohort study (Canadian Partnership for Tomorrow Project - CPTP), we reviewed the literature to identify evidence that can be used by experts to classify the effects of known EDCs more precisely as estrogenic, anti-estrogenic, androgenic and/or anti-androgenic. The purpose of this endeavour is ultimately aimed to inform future conceptualization of exposure to EDCs, via modes of action, that may have different impacts on disease etiologies.

\section{Methods}

\subsection{Identification of EDCs for the current review}

In the epidemiologic study being conducted to assess occupational exposure to EDCs and colorectal cancer risk, occupational exposures to EDCs are assessed using the Canadian Job Exposure Matrix (CANJEM) (38). Briefly, CANJEM provides Canadian-relevant 
153 information on the probability, frequency and intensity of exposure to a list of 258 agents for a

154 given job code in a specific time period. To identify which agents present in CANJEM would 155 comprise the EDCs of interest for this review, we cross-matched the list of CANJEM agents to

156 those chemicals, irrespective of the mode of action, that have been identified as EDCs or 157 potential EDCs, by the European Commission following a thorough scientific assessment 158 (available at: http://ec.europa.eu/environment/archives/docum/pdf/bkh_annex_13.pdf). A 159 second source, an EDC-JEM (39), defined distinct classes of substances that represent the 160 majority of EDCs found in workplaces. Briefly, using a list of substance with potential 161 endocrine disrupting potency established from a literature review, three occupational hygienists 162 independently assigned exposure scores to occupations. From these two sources, 26 potential 163 EDCs of interest were selected for review.

\section{$164 \quad 2.2$ Literature search strategy}

165 In order to provide a body of evidence for the expert panel to classify the most likely 166 mode(s) of action of each potential EDC as estrogenic and/or, anti-estrogenic and/or, 167 androgenic and/or anti-androgenic, a literature search stratified into 4 tiers was conducted.

In Tier 1, national and international agency reports, which encompassed evaluations of 169 published in vitro, in vivo and/or data from an intact organism (including humans), were 170 prioritized. The literature search was conducted in Google using a combination of keywords 171 "substance name" and "endocrine effect" (40-50). Any definitive conclusions on the presence 172 or absence of (anti-)estrogenic or (anti-)androgenic effects were summarized and the agent was 173 not further reviewed in Tiers 2 and 3. If the conclusions regarding any of the four effects from 174 the report were qualified (e.g. "estrogenic effect cannot be excluded"), this specific effect was 175 included in Tier 2 for evaluation. If no such report was identified for a given agent, a Tier 2 176 review was carried out. 
In Tier 2, the PubMed database was used to identify published review articles and metaanalysis articles. The combination of keywords used was: "substance name" and "androgen" or "estrogen" or "endocrine effect". A time constraint was applied only for substances for which a report was found in Tier 1 but the conclusions of the report were qualified; in this case, only review articles published after the report were considered (51-57). The objective of the

182 literature search was similar to that used in Tier 1, to identify conclusions regarding the possible estrogenic, anti-estrogenic, androgenic and/or anti-androgenic effect. Again, if no review was found or no firm conclusions were stated in the review for a given agent, it was included in the Tier 3 review.

In Tier 3, the PubMed database was used to identify primary research studies conducted in vitro, in vivo or in humans. Two search strategies were used. First, using the systematic reviews identified in Tier 2, we identified the original studies and abstracted information on their methods and results (58-136). Second, for the EDCs that were not have a systematic review, we conducted our own review using the combination of keywords: "substance name" and for:

- effects related to estrogenic or anti-estrogenic ((anti-)estrogenic) effects: "estrogen receptor" or "estrogen levels" or "aromatase (CYP19)"

- effects related to androgenic or anti-androgenic ((anti-)androgenic) effects: "androgen receptor" or "testosterone levels" or "PPAR $\gamma$ " or "INSL3"

- effects on enzymes and hormones that can impact estrogen and androgen levels: "CYP17" or "17beta-HSD" or "5alpha reductase" or "FSH" or "LH"; where CYP19, PPAR $\gamma$, INSL3, CYP17, 17beta-HSD, 5alpha reductase are enzymes or hormones involved in the development of male and female fertility(137-143). These keywords were selected to ensure a broad capture of mechanistic studies that may have examined the 
201 potential for endocrine disruption of our selected EDCs but not have included "endocrine 202 effects" in their keywords.

In Tier 4, to complement our literature search strategy in Tiers 1 to 3, we used the US-

204 Environment Protection Agency (EPA) Toxicity Forecaster (144). ToxCast ${ }^{\mathrm{TM}}$ uses high205 throughput screening methods and computational toxicology approaches to rank and prioritize 206 chemicals. We searched the ToxCast ${ }^{\mathrm{TM}}$ database to identify the bioactivity profiles of our 26 207 EDCs of interest in relation to estrogen receptor and androgen receptor activity.

\subsection{Expert Evaluation}

Three members of the team (R. Pricyhystalova, E. Caron-Beaudoin and E. Dirkx with expertise in Occupational and Process Safety, Biology, and Biomedical sciences, respectively)

211 reviewed the literature in relation to 24 of the 26 potential EDCs of interest; no literature on the 212 possible (anti-)estrogenic or (anti-)androgenic effects was found for octachlorostyrene and phenol isooctyl. Based on the literature reviews conducted in Tiers 1 to 4 , the available evidence was summarised for the 24 remaining potential EDCs (see Supplementary Materials). Subsequently, an expert panel consisting of seven experts with experience in endocrine 216 disruption, spanning the fields of toxicology, environmental sciences and epidemiology was assembled. The expert panel was tasked with individually reviewing the evidence and categorizing the likelihood for each EDC to affect estrogenic, anti-estrogenic, androgenic and/or anti-androgenic activity. All 24 EDCs were reviewed by two experts independently, with each expert reviewing between six to eight summaries. Specifically, for each of the four effects,

221 the experts were asked to evaluate activity, based on the following categories:

- "No" (there is no or very little evidence suggesting there is such an effect),

- "Unlikely" (it is more likely than not that there is no such effect),

- "Possibly" (there is equal evidence for and against such an effect),

- "Probably" (it is more likely than not that there is such an effect) and, 
- "Yes" (there is strong evidence suggesting such an effect).

Any differences in assessment between the two reviewers for a given EDC were reconciled as follows. Where the evaluations provided by each expert differed by one level (e.g. if expert 1 concluded "No" while expert 2 concluded "Unlikely") then the more conservative conclusion was taken (i.e. in the above scenario, "No" would be the conclusion). In case there was any discordance by more than one level (e.g. if expert 1 concluded "No" while expert 2 concluded "Possibly"), then a third expert was asked to review and assess the evidence (hereafter referred to as the "second round" of evaluations). The final assessment in this case was provided by the median assessment, which was either the middle or majority assessment.

E.g. for carbon disulphide and its anti-androgenic effect: Expert 1 concluded "Yes," Expert 2 concluded "Possibly" and Expert 3 concluded "Unlikely"; in this scenario, the final assessment was "Possibly" anti-androgenic effect.

\section{Results}

\subsection{Summary of the Literature Synthesis}

Table 1 summarizes the Tier 1 and 2 reviews of the 24 potential EDCs. Specifically, national and international agency reports were identified for nine substances in Tier 1 (bis(2ethylhexyl phthalate, copper, bisphenol A, butylbenzyl phthalate, dibutyl phthalate,

244 dicyclohexyl phthalate, diisodecyl phthalate, diisononyl phthalate, polychlorinated biphenyl).

245 For (anti-)estrogenic effects, conclusive evidence was found in reports from Tier 1 for 246 bisphenol A and polychlorinated biphenyl. For (anti-)androgenic effects, conclusive evidence 247 was available from Tier 1 reports for bis(2-ethylhexyl) phthalate, bisphenol A, butylbenzyl 248 phthalate, dibutyl phthalate, dicyclohexyl phthalate, diisononyl phthalate and polychlorated 249 biphenyl. For bisphenol A and polychlorinated biphenyl there was conclusive evidence found 250 in Tier 1 for both (anti-)estrogenic and (anti-)androgenic effects. 
252 found for nonylphenol and cadmium. Additionally, the evidence on (anti-)androgenic effects 253 was available for aluminum and cadmium from Tier 2 reviews. Table 2 presents an overview 254 of the primary research studies found as part of the Tier 3 review.

Finally, Table 3 presents the results of the bioactivity characterisation of our 24 potential EDCs using ToxCast in relation to estrogen and androgen receptor activity (Tier 4). For the majority of the substances, no data were found in ToxCast. In contrast, diethyl phthalate, bisphenol A, butylbenzyl phthalate, dibutyl phthalate, dicyclohexyl phthalate and phenol had data on their effects on the estrogen receptor. For the androgen receptor, data were found for diethyl phthalate, dibutyl phthalate, bisphenol A, dicyclohexyl phthalate and phenol.

\subsection{Results of Expert Panel Evaluation}

After the first round of expert evaluation, discordances (defined as differences in evaluations by more than one level) were found for 10 of the 24 potential EDCs for which a second round of evaluation was conducted. Figure 1 presents the final results from the expert panel evaluation for each agent. Similarly, Table 4 presents an alternative summary of the final conclusions reached by the expert panel for each agent. The major uses of each agent in the occupational setting are summarized in Table 5. Any discordances and the final conclusions reached for each agent are presented as follows.

\section{Bis(2-ethylhexyl) phthalate}

No discordance was found for any of the four effects. The experts concluded that bis(2ethylhexyl) phthalate has possible estrogenic and probable anti-androgenic effects, but no antiestrogenic and androgenic effects. 
No discordance was found for any of the four effects. The experts concluded that lead 278 has possible estrogenic, probable anti-estrogenic and definite anti-androgenic effects, but no 279 androgenic effect.

280 Arsenic

Discordance between the first two experts on the anti-estrogenic effects of arsenic necessitated a third expert review. After the second round of evaluations, the experts concluded that arsenic has probable estrogenic, probable anti-estrogenic, unlikely androgenic and definite anti-androgenic effects.

Mercury

No discordance was found for any of the four effects. The experts concluded that mercury has possible estrogenic, unlikely anti-estrogenic and possible anti-androgenic effects but no androgenic effect.

\section{Nonylphenol}

No discordance was found for any of the four effects. The experts concluded that nonylphenol has definite estrogenic, unlikely androgenic and probable anti-androgenic effects,

292 but no anti-estrogenic effect.

Copper

No discordance was found for any of the four effects. The experts concluded that copper 295 has probable estrogenic and possible anti-androgenic effects, but no anti-estrogenic and 296 androgenic effect.

\section{Toluene}

There was discordance between the experts in the androgenic effects of toluene. After

299 the second round of evaluations, the experts concluded that toluene has possible anti-estrogenic

300 and probable anti-androgenic effects, but has no estrogenic and androgenic effects. 
Discordances in the anti-estrogenic and anti-androgenic effects of aluminium were found. After the second round of evaluations, the experts concluded that aluminium has possible estrogenic, possible anti-estrogenic and possible anti-androgenic effects, but has no androgenic 305 effect.

\section{Diethyl phthalate}

No discordance was found for any of the four effects. The experts concluded that diethyl

308 phthalate has possible estrogenic and possible anti-androgenic effects, but has no anti309 estrogenic and androgenic effects.

$310 \quad$ Styrene

Discordance between the experts for the anti-androgenic effects was found. After the

312 second round of evaluations, the experts concluded that styrene has no anti-estrogenic, estrogenic, anti-androgenic or androgenic effects.

\section{Bisphenol A}

No discordance was found for any of the four effects. The experts concluded that

316 bisphenol A has definite estrogenic, and probable anti-androgenic effects, but no anti-estrogenic 317 and androgenic effects.

\section{Butylbenzyl phthalate}

No discordance was found for any of the four effects. The experts concluded that 320 butylbenzyl phthalate has possible estrogenic and definite anti-androgenic effects, but has no 321 anti-estrogenic and androgenic effects.

\section{Cadmium}

No discordance was found for any of the four effects. The experts concluded that cadmium has probable estrogenic and androgenic effects, but has no anti-estrogenic and antiandrogenic effects. 


\section{Carbon disulphide}

Discordance was found for the anti-estrogenic effects between the initial two experts and thus, a third expert was invited to provide an evaluation. After the second round of evaluations, the experts concluded that carbon disulphide has unlikely anti-estrogenic and possibly anti-androgenic effects, but has no estrogenic and androgenic effects.

\section{Dibutyl phthalate}

Discordance for the anti-estrogenic effects necessitated a third expert review. After the second round of evaluations, the experts concluded that dibutyl phthalate has possible estrogenic, unlikely anti-estrogenic and definite anti-androgenic effects, but has no androgenic 335 effect.

\section{Dicyclohexyl phthalate}

Discordance was found for the androgenic effects between the two experts. After the second round of evaluations, the experts concluded that dicyclohexyl phthalate has possible estrogenic, possible anti-estrogenic and certain anti-androgenic effects, but has no androgenic 340 effect.

\section{Diisodecyl phthalate}

No discordances were found for the four effects. The experts concluded that diisodecyl

343 phthalate has unlikely androgenic effects, and no estrogenic, anti-estrogenic and anti344 androgenic effect.

\section{Diisononyl phthalate}

Discordances for both the estrogenic and androgenic effects were found between the

347 first two experts. After the second round of evaluations, the experts concluded that diisononyl 348 phthalate has unlikely estrogenic, unlikely anti-estrogenic, unlikely androgenic and probable 349 anti-androgenic effects. 


\section{Ethylene glycol}

No discordances were found for the four effects. The experts concluded that ethylene

353 glycol has possible estrogenic, but has no anti-estrogenic, androgenic and anti-androgenic 354 effects.

\section{Polychlorinated biphenyls}

No discordances were found for the four effects. The experts concluded that polychlorinated biphenyls have probable estrogenic, probable anti-estrogenic and possible antiandrogenic effects, but have no androgenic effect.

\section{Perchloroethylene (also known as Tetrachloroethylene)}

No discordances were found for the four effects. The experts concluded that perchloroethylene has no (anti-)estrogenic or (anti-)androgenic effects.

\section{Phenol}

No discordances were found for the four effects. The experts concluded that phenol has

364 no (anti-)estrogenic or (anti-)androgenic effects.

\section{Trichloroethylene}

Discordances were found for the (anti-)estrogenic and (anti-)androgenic effects in the

367 first round of evaluations. After the second round of evaluations, the experts concluded that 368 trichloroethylene has unlikely anti-estrogenic, unlikely androgenic and possible anti369 androgenic effects, and no estrogenic effect.

$370 \quad$ Xylene expert review. After the second round of evaluations, the experts concluded that xylene has unlikely estrogenic effect, and no anti-estrogenic effects, androgenic and anti-androgenic

374 effects. 
4. Discussion

\subsection{Summary of our Literature Search and Expert Panel Evaluation}

This review focused on classifying the effects of EDCs on sex hormones based on the current scientific evidence and expert opinion. In total, seven agents were categorised as having "strong" evidence for their effect on sex hormone function; where, five were classified as having an anti-androgenic mode of action (lead, arsenic, butylbenzyl phthalate, dibutyl phthalate and dicyclohexyl phthalate), and two as estrogenic (nonylphenol and bisphenol A). Four of these seven agents (nonylphenol, bisphenol A, dibutyl phthalate and dicyclohexyl phthalate) with "strong" evidence had Tier 1 and 2 evidence identified using our literature search strategy and thus, arguably had more data to be considered by the experts.

From the expert evaluation, ten of the reviewed agents were judged to have "probable" evidence to classify their effect on sex hormone function; two were classified as estrogenic (copper and cadmium), one as anti-estrogenic (lead), one as androgenic (cadmium), and five as anti-androgenic (bis(2-ethylhexyl)phthalate, nonylphenol, toluene, bisphenol A and diisonoyl phthalate). Two agents (arsenic and polychlorinated biphenyls) had conclusions supporting both "probably" estrogenic and anti-estrogenic effects. We identified literature within the Tier 1 and 2 search strategy for five of these ten agents with "probable" evidence (nonylphenol, bisphenol A, diisonoyl phthalate, cadmium, and polychlorinated biphenyls).

For styrene, phenol, xylene, perchloroethylene and diisodecyl phthalate the expert panel concluded that there is insufficient evidence for an effect on sex hormone function. Indeed, no literature was found in Tiers 1 and 2 regarding these agents (with the exception of diisodecyl phthalate). While in Tier 3, very few studies were found examining the effect of these agents (with the exception of styrene) on sex hormone pathways. 


\subsection{Utility of this Research}

As workers in many industries are subject to concurrent exposure to several chemical contaminants, the combined health effects of such multi-exposures should not be overlooked. We conceptualized one approach to assess the health effects of endocrine disruption associated with occupational exposures via the categorization of agents according to their biological mode of actions on sex hormones. $(36,37,145)$

Within the context of an epidemiologic study investigating occupational exposures to EDCs, we posit that the different effects of EDCs on functioning of sexual hormones (i.e. estrogens and androgens) should be incorporated into risk analyses, given the growing literature supporting sex hormone imbalance in some cancer etiology. Phthalates and bisphenol A could be taken as an example where both agents are used within the production of plastic products. In these occupational settings, workers could be exposed to both substances concomitantly and it is difficult to predict the effect on endocrine disruption and/or subsequent health effects as bisphenol A likely operates through an estrogenic mode of action while phthalates (taken as a whole) are antagonists to androgens. Using our approach, we would consider both phthalates and bisphenol A separately to interrogate whether estrogenic versus anti-androgenic perturbations are more relevant for cancer development. In a similar manner, co-exposures to multiple EDCs with the same (anti-)estrogenic or (anti-) androgenic pathway could be summed into a total exposure when analysing exposure in relation to a health effect. For example, a worker exposed to both nonylphenol and bisphenol A, two chemicals with estrogenic effects may have higher risks associated with their co-exposures than another worker who is exposed to one or neither of the two agents. The objective of our review was to provide the backbone needed for such a synthesis of exposure profiles for analysis in future epidemiologic studies. 


\subsection{Limitations}

Recent work by others has similarly put forth approaches to identify EDCs and integrate the literature on the hazards associated with exposure $(36,37,145)$. Notably, the consensus statement by La Merrill et al. proposes ten key characteristics in which to support the identification of EDCs and systematically review the vast literature on EDC hazards; diethylstilbestrol, bisphenol $\mathrm{A}$ and perchlorate were used as examples to illustrate this approach. Broadly, this approach has the advantage of: identifying those chemicals which act upon the same key characteristics and, within a chemical, be useful for "connecting the dots" between different modes of action or adverse outcome pathways and/or identifying gaps in knowledge. We focused our review only on the effect of potential EDCs on perturbing sex hormone function; thus, effects on other endocrine pathways cannot be excluded. Applying the approach by La Merrill et al. could, in future, provide a more concerted and comprehensive overview of the state of knowledge of the chemicals under review.

Further, for some agents like arsenic, the experts found evidence supporting both estrogenic and anti-estrogenic effects. One important element in determining the likelihood of endocrine disruption in humans is the dose at which effects occurred in experimental models (cells, animals, humans). In the absence of dose / potency / exposure information, this review therefore is only a preliminary hazard assessment. However, as our review did not consider the impact of dose we cannot discuss the plausibility of this hypothesis. It is noteworthy that parallel efforts in computational biology are being made to identify and classify EDCs. Briefly, computational algorithms can be used to predict the activity of untested compounds with suspected endocrine disrupting properties (e.g. affinity to estrogen and androgen receptors), and prioritize those potentially active chemicals for future biological testing (146). Future evaluation efforts may consider integrating the predictive affinity of suspected EDCs, obtained 
through these computation algorithms, as a way of standardizing the assessment of dose and adverse health effects.

Our approach was not a systematic attempt to capture all the available evidence for our selected EDCs for subsequent expert review. Though a four-tiered approach was developed to synthesize the evidence, we do not claim to have captured all possible mechanisms related to sex hormones disruption in our review. For example, sex hormone binding globulin, which influences hormone distribution, was not included as a keyword during our Tier 3 review. Nevertheless, with our chosen keywords, we posit that we would still capture the effect of altered hormone transport by the hormone plasma levels, including hormones like FSH and LH which are part of the feedback loops and regulate the production of steroid hormones like androgen and estrogen. Other potential mechanisms that our keywords did not target include epigenetic modifications in hormone-producing or hormone-responsive cells; hormone transport across cell membranes and; those which alters hormone metabolism or clearance. In addition, we did not use Medical Subject Headings while performing our search in Pubmed®; thus, we cannot exclude the possibility of having missed some published evidence. Further, we did not assess the quality of each study included in our review (e.g. the compliance of review articles with PRISMA guidelines), partly due to resource constraints but also that the use of evidence drawn from International and National bodies (Tier 1) and systematic reviews (Tier 2) assured already, a degree of quality. Nevertheless, particularly for the review of the literature in Tier 3, providing a completeness in reporting, as illustrated by Bonde et al., could have an impact on the reliability of the conclusions reached by our experts.

Many of our agents of interest lacked sufficient evidence for expert evaluation. Indeed, this exercise highlighted a real need for more epidemiological and toxicological studies to extend the scientific knowledge base about the possible endocrine effects of these substances. Expert panels are useful when specialized opinion or conclusion is required for evaluation. 
475 Generally, a greater variety of experts engaged in the evaluation based on various fields of expertise can have an impact on the final conclusions. The limitation of our expert panel was

477 that it consisted of only seven experts and that each substance was reviewed by only two experts 478 (or three in case of discordances); it can be presumed that the involvement of more experts 479 would have increased the robustness of our conclusions.

\section{Conclusion} International research efforts to better understand the presence of EDCs and related environmental effects have intensified over the past three decades and have led to an increasing level of concern and action on EDCs. To date, substantial efforts have been made by a wide variety of stakeholders across numerous sectors worldwide in identifying and categorizing EDCs. Overall this was an endeavour to summarize the current evidence concerning the effect of potential EDCs, common in the occupational environment, operating through either an estrogenic, anti-estrogenic, androgenic or anti-androgenic mode of action. The conclusions from this review could be used in concert with various occupational exposure assessment approaches like CANJEM to incorporate estimates of modes of action which would allow

491 further hypotheses to be tested in epidemiological studies regarding multi-exposure to EDCs 492 and health outcomes.

\section{List of abbreviations}

495 17beta-HSD - 17 beta-hydroxysteroid dehydrogenase

496 AR - Androgen receptor

497 CANJEM - Canadian Job Exposure Matrix

498 CPTP - Canadian Partnership for Tomorrow Project

499 CYP17 - Cytochrome P450 17 $\alpha$ Hydroxylase/17,20 Lyase 
CYP19 - Aromatase cytochrome P450

501 EDC - Endocrine Disrupting Chemicals

502 ER - Estrogen receptor

503 FSH - Follicle-stimulating hormone

504 INSL3 - Insulin-like 3

505 JEM - Job Exposure Matrix

506 LH - Luteinizing hormone

507 PPAR $\gamma$ - Peroxisome proliferator-activated receptors gamma

508 PVC - Polyvinyl chloride

509 ToxCast - Toxicity Forecaster

510 US-EPA - United States - Environmental Protection Agency

511

\section{Acknowledgements}

Funding for the study was provided by Canadian Institutes for Health Research (Funding 515 Reference Number 156077). Dr. Ho holds a Sex and Gender Science Chair in Cancer Research 516 from the Canadian Institutes for Health Research. She is currently supported by the Cancer 517 Research Society, Fonds de recherche du Québec - Santé (FRQS) and Ministère de l'Économie, 518 de la Science et de l'Innovation du Québec (MESI).

\section{Conflict of Interest}

521 J. Hynes declared working relations with the styrene industry and users, thus, did not contribute 522 to the review on styrene. All other authors have no conflicts of interest to declare. 
525 1. Centers for Disease Control and Prevention (CDC). Fourth National Report on Human Exposure to Environmental Chemicals, Updated Tables. 2017; volume 1. [cited 2020 April]; Available from: https://www.cdc.gov/biomonitoring/pdf/FourthReport_UpdatedTables_Volume1_Jan2017.pd $\underline{f}$.

2. Damstra T, Barlow S, Bergman A, Kavlock R, Van Der Kraak G. International Programme on Chemical Safety, Global assessment of the state-of-the-science of endocrine disruptors. 2002. [cited 2020 April]; Available from: http://www.who.int/ipcs/publications/new issues/endocrine disruptors/en/. worldwide burden of cancer in 2008: GLOBOCAN 2008. International Journal of Cancer. 2010;127(12):2893-917.

4. Calafat AM, Ye X, Wong LY, Reidy JA, Needham LL. Exposure of the U.S. population to bisphenol A and 4-tertiary-octylphenol: 2003-2004. Environ Health Perspect. 2008;116(1):39-44.

5. IARC. Arsenic, metals, fibres, and dusts. IARC Monogr Eval Carcinog Risks Hum. 2012;100(Pt C):11-465.

6. IARC. Polychlorinated biphenyls and polybrominated biphenyls. IARC Monogr Eval Carcinog Risks Hum. 2016; 107:9-500.

7. IARC. Some organophosphate insecticides and herbicides. IARC Monogr Eval Carcinog Risks Hum. 2017; 112.

8. Gore AC, Chappell VA, Fenton SE, Flaws JA, Nadal A, Prins GS, et al. EDC-2: The Endocrine Society's Second Scientific Statement on Endocrine-Disrupting Chemicals. Endocr Rev. 2015;36(6):E1-E150.

9. Jeng HA. Exposure to endocrine disrupting chemicals and male reproductive health. Front Public Health. 2014;2:55.

10. Sweeney MF, Hasan N, Soto AM, Sonnenschein C. Environmental endocrine disruptors: Effects on the human male reproductive system. Rev Endocr Metab Disord. 2015;16(4):341-57.

11. Crain DA, Janssen SJ, Edwards TM, Heindel J, Ho SM, Hunt P, et al. Female reproductive disorders: the roles of endocrine-disrupting compounds and developmental timing. Fertil Steril. 2008;90(4):911-40.

12. Smarr MM, Kannan K, Buck Louis GM. Endocrine disrupting chemicals and endometriosis. Fertil Steril. 2016;106(4):959-66.

13. Rachon D. Endocrine disrupting chemicals (EDCs) and female cancer: Informing the patients. Rev Endocr Metab Disord. 2015;16(4):359-64.

14. Burns KA, Korach KS. Estrogen receptors and human disease: an update. Arch Toxicol. 2012;86(10):1491-504.

15. Folkerd E, Dowsett M. Sex hormones and breast cancer risk and prognosis. Breast. 2013;22 Suppl 2:S38-43.

16. Dobbs RW, Malhotra NR, Greenwald DT, Wang AY, Prins GS, Abern MR. Estrogens and prostate cancer. Prostate Cancer Prostatic Dis. 2019;22(2):185-94.

17. Chuffa LG, Lupi-Junior LA, Costa AB, Amorim JP, Seiva FR. The role of sex hormones and steroid receptors on female reproductive cancers. Steroids. 2017;118:93-108. 18. Gibson DA, Simitsidellis I, Collins F, Saunders PTK. Endometrial Intracrinology: Oestrogens, Androgens and Endometrial Disorders. Int J Mol Sci. 2018;19(10).

19. White A, Ironmonger L, Steele RJC, Ormiston-Smith N, Crawford C, Seims A. A review of sex-related differences in colorectal cancer incidence, screening uptake, routes to diagnosis, cancer stage and survival in the UK. BMC Cancer. 2018;18(1):906. 

Postmenopausal levels of endogenous sex hormones and risk of colorectal cancer. Cancer Epidemiol Biomarkers Prev. 2009;18(1):275-81. 21. Grodstein F, Newcomb PA, Stampfer MJ. Postmenopausal hormone therapy and the risk of colorectal cancer: a review and meta-analysis. Am J Med. 1999;106(5):574-82. 22. La Vecchia C, Franceschi S. Reproductive factors and colorectal cancer. Cancer 580 Causes Control. 1991;2(3):193-200. $\mathrm{ML}$, et al. Colorectal cancer in relation to postmenopausal estrogen and estrogen plus progestin in the Women's Health Initiative clinical trial and observational study. Cancer Epidemiol Biomarkers Prev. 2009;18(5):1531-7.

585 24. Combarnous Y, Nguyen TMD. Comparative Overview of the Mechanisms of Action 586 of Hormones and Endocrine Disruptor Compounds. Toxics. 2019;7(1).

587 25. Sonnenschein C, Soto AM. An updated review of environmental estrogen and androgen mimics and antagonists. J Steroid Biochem Mol Biol. 1998;65(1-6):143-50. 26. Endocrine Society. Impact of EDCs on Reproductive Systems. 2019. [cited 2020 April]; Available from: https://www.endocrine.org/topics/edc/what-edcs-are/commonedcs/reproduction.

27. Ropero, A.B. and al., Rapid endocrine disruption: environmental estrogen actions triggered outside the nucleus. J Steroid Biochem Mol Biol, 2006. 102(1-5): 163-9.

28. Luccio-Camelo DC, Prins GS. Disruption of androgen receptor signaling in males by environmental chemicals. J Steroid Biochem Mol Biol. 2011;127(1-2):74-82.

29. Endocrine Society. Endocrinology Glossary. 2018. [cited 2020 April]; Available from: https://www.endocrine.org/news-room/glossary.

30. Kortenkamp A. Ten Years of Mixing Cocktails: A Review of Combination Effects of Endocrine-Disrupting Chemicals. 2007;115(Suppl 1):98-105.

31. Lauretta R, Sansone A, Sansone M, Romanelli F, Appetecchia M. Endocrine Disrupting Chemicals: Effects on Endocrine Glands. Front Endocrinol (Lausanne). 2019;10:178-.

32. Margina D, Nitulescu GM, Ungurianu A, Mesnage R, Goumenou M, Sarigiannis D, et al. Overview of the effects of chemical mixtures with endocrine disrupting activity in the context of real-life risk simulation (RLRS): An integrative approach (Review). 2019;1:15764.

33. Ribeiro E, Ladeira C, Viegas S. EDCs Mixtures: A Stealthy Hazard for Human Health? Toxics. 2017;5(1):5.

34. Sobolewski M, Conrad K, Allen JL, Weston H, Martin K, Lawrence BP, et al. Sexspecific enhanced behavioral toxicity induced by maternal exposure to a mixture of low dose endocrine-disrupting chemicals. Neurotoxicology. 2014;45:121-30.

35. Woodruff TJ. Bridging epidemiology and model organisms to increase understanding of endocrine disrupting chemicals and human health effects. J Steroid Biochem Mol Biol. 2011;127(1-2):108-17.

36. La Merrill MA, Vandenberg LN, Smith MT, Goodson W, Browne P, Patisaul HB, et al. Consensus on the key characteristics of endocrine-disrupting chemicals as a basis for hazard identification. Nat Rev Endocrinol. 2020;16(1):45-57. 37. Bonde JP, Flachs EM, Rimborg S, Glazer CH, Giwercman A, Ramlau-Hansen CH, et al. The epidemiologic evidence linking prenatal and postnatal exposure to endocrine disrupting chemicals with male reproductive disorders: a systematic review and metaanalysis. Hum Reprod Update. 2016;23(1):104-25.

38. Lavoue J. CANJEM Occupational Exposure Information System [Internet]. 2015. [cited 2020 April]; Available from: http://www.canjem.ca/. 
39. Brouwers MM, van Tongeren M, Hirst AA, Bretveld RW, Roeleveld N. Occupational exposure to potential endocrine disruptors: further development of a job exposure matrix.

626 Occup Environ Med. 2009;66(9):607-14. 40. Joint FAO/WHO Expert Committee on Food Additives (JECFA). Evaluation of Certain Food Additives and Contaminants: Eightieth Report of the Joint FAO/WHO Expert Committee on Food Additives. World Health Organization. (WHO), Geneva, Switzerland (2016). WHO Technical Report Series 995. 132pp.

41. Joint FAO/WHO Expert Committee on Food Additives (JECFA). Safety Evaluation of Certain Food Additives and Contaminants: Prepared by the Eightieth Meeting of the Joint FAO/WHO Expert Committee on Food Additives (JECFA). World Health Organization (WHO), Geneva, Switzerland (2015). WHO Food Additives Series 71. 142pp.

42. BKH. Endocrine disruptors: study on gathering informations on 435 substances with insufficient data. 2002:Annex 7. [cited 2020 April]; Available from: https://ec.europa.eu/environment/chemicals/endocrine/pdf/bkh_report.pdf. 43. BKH. Endocrine disruptors: study on gathering informations on 435 substances with insufficient data. 2002:Annex 12. [cited 2020 April]; Available from: https://ec.europa.eu/environment/chemicals/endocrine/pdf/bkh_report.pdf. 44. ECHA. Evaluation of new scientific evidence concerning DINP and DIDP in relation to entry 52 of Annex XVII to REACH Regulation (EC) No 1907/2006. 2013. [cited 2020 April]; Available from: https://echa.europa.eu/documents/10162/31b4067e-de40-4044-93e89c9ff1960715.

45. ECHA. Support document of the opinion of the member state committee for the identification of dibutyl phthalate (DBP). 2014. [cited 2020 April]; Available from: https://echa.europa.eu/documents/10162/e4edaefa-84a4-4972-89f0-470cd64bc949. 46. ECHA. Opinion of the member state committee for identification of benzyl butyl phthalate (BBP) as a substance of very high concern. 2014. [cited 2020 April]; Available from: https://www.echa.europa.eu/documents/10162/02d9dcca-b07b-448b-8331f7209af10d16.

47. ECHA. Support document to the opinion of the member state committee for identification of Bis(2-ethylhexyl) phthalate (DEHP). 2014. [cited 2020 April]; Available from:

https://echa.europa.eu/documents/10162/21833221/svhc_msc_opinion_support_document_de hp_20141211_en.pdf.

48. ECHA. Annex XV report - Proposal for identification of a substance of very high concern on the basis of the criteria set out in REACH Article 57. 2015. [cited 2020 April]; Available from: https://echa.europa.eu/documents/10162/cdc07dd9-0f7e-4b07-97211a51c6f627af.

49. ECHA. Prioritisation of substances of very high concern (SVHCs) for inclusion in the Authorisation List (Annex XIV). 2014. [cited 2020 April]; Available from:

https://echa.europa.eu/documents/10162/13640/gen_approach_svhc_prior_in_recommendatio ns_en.pdf.

50. INSERM. Reproduction et environnement, Expertise collective. Inserm, Paris. 2011. [cited 2020 April]; Available from: www.inserm.fr/content/download/38030/244999/.../reproduction_et_environnement.pdf2011. 51. Byrne C, Divekar SD, Storchan GB, Parodi DA, Martin MB. Cadmium-a metallohormone? Toxicol Appl Pharmacol. 2009;238(3):266-71.

52. Byrne C, Divekar SD, Storchan GB, Parodi DA, Martin MB. Metals and breast cancer. J Mammary Gland Biol Neoplasia. 2013;18(1):63-73.

53. Darbre PD. Metalloestrogens: an emerging class of inorganic xenoestrogens with potential to add to the oestrogenic burden of the human breast. J Appl Toxicol. 
675 54. Noorimotlagh Z, Haghighi NJ, Ahmadimoghadam M, Rahim F. An updated

676 systematic review on the possible effect of nonylphenol on male fertility. Environ Sci Pollut

677 Res Int. 2017;24(4):3298-314.

678 55. Radke EG, Braun JM, Meeker JD, Cooper GS. Phthalate exposure and male reproductive outcomes: A systematic review of the human epidemiological evidence. Environ 680 Int. 2018;121(Pt 1):764-93.

681 56. Takiguchi M, Yoshihara S. New aspects of cadmium as endocrine disruptor. Environ 682 Sci. 2006;13(2):107-16.

683 57. Witorsch RJ, Thomas JA. Personal care products and endocrine disruption: A critical 684 review of the literature. Crit Rev Toxicol. 2010;40 Suppl 3:1-30.

685 58. Ajayi O, Charles-Davies M, Anetor J, Ademola A. Pituitary, Gonadal, Thyroid 686 Hormones and Endocrine Disruptors in Pre and Postmenopausal Nigerian Women with ER-, PR- and HER-2-Positive and Negative Breast Cancers. Med Sci (Basel). 2018;6(2). 59. Akingbemi BT, Sottas CM, Koulova AI, Klinefelter GR, Hardy MP. Inhibition of testicular steroidogenesis by the xenoestrogen bisphenol A is associated with reduced pituitary luteinizing hormone secretion and decreased steroidogenic enzyme gene expression in rat Leydig cells. Endocrinology. 2004;145(2):592-603.

60. Bistakova J, Forgacs Z, Bartos Z, Szivosne MR, Jambor T, Knazicka Z, et al. Effects of 4-nonylphenol on the steroidogenesis of human adrenocarcinoma cell line (NCI-H295R). J Environ Sci Health A Tox Hazard Subst Environ Eng. 2017;52(3):221-7.

61. Bitsch N, Dudas C, Korner W, Failing K, Biselli S, Rimkus G, et al. Estrogenic activity of musk fragrances detected by the E-screen assay using human mcf-7 cells. Arch Environ Contam Toxicol. 2002;43(3):257-64.

62. Bonefeld-Jorgensen EC, Long M, Hofmeister MV, Vinggaard AM. Endocrinedisrupting potential of bisphenol A, bisphenol A dimethacrylate, 4-n-nonylphenol, and 4-noctylphenol in vitro: new data and a brief review. Environ Health Perspect. 2007;115 Suppl 1:69-76.

63. Brehm E, Rattan S, Gao L, Flaws JA. Prenatal Exposure to Di(2-Ethylhexyl) Phthalate Causes Long-Term Transgenerational Effects on Female Reproduction in Mice.

Endocrinology. 2018;159(2):795-809.

64. Chamkhia N, Sakly M, Rhouma KB. Male reproductive impacts of styrene in rat. Toxicol Ind Health. 2006;22(8):349-55.

65. Choe SY, Kim SJ, Kim HG, Lee JH, Choi Y, Lee H, et al. Evaluation of estrogenicity of major heavy metals. Sci Total Environ. 2003;312(1-3):15-21.

66. Date K, Ohno K, Azuma Y, Hirano S, Kobayashi K, Sakurai T, et al. Endocrinedisrupting effects of styrene oligomers that migrated from polystyrene containers into food. Food Chem Toxicol. 2002;40(1):65-75.

67. Davey JC, Bodwell JE, Gosse JA, Hamilton JW. Arsenic as an endocrine disruptor: effects of arsenic on estrogen receptor-mediated gene expression in vivo and in cell culture. Toxicol Sci. 2007;98(1):75-86.

68. Denham M, Schell LM, Deane G, Gallo MV, Ravenscroft J, DeCaprio AP, et al. Relationship of lead, mercury, mirex, dichlorodiphenyldichloroethylene, hexachlorobenzene, and polychlorinated biphenyls to timing of menarche among Akwesasne Mohawk girls. Pediatrics. 2005;115(2):e127-34.

69. Di Lorenzo M, Forte M, Valiante S, Laforgia V, De Falco M. Interference of dibutylphthalate on human prostate cell viability. Ecotoxicol Environ Saf. 2018;147:565-73. 70. Ernst J, Jann JC, Biemann R, Koch HM, Fischer B. Effects of the environmental contaminants DEHP and TCDD on estradiol synthesis and aryl hydrocarbon receptor and peroxisome proliferator-activated receptor signalling in the human granulosa cell line KGN. 
Mol Hum Reprod. 2014;20(9):919-28.

71. Eum KD, Weisskopf MG, Nie LH, Hu H, Korrick SA. Cumulative lead exposure and age at menopause in the Nurses' Health Study cohort. Environ Health Perspect. 2014;122(3):229-34. 72. Fossato da Silva DA, Teixeira CT, Scarano WR, Favareto AP, Fernandez CD, Grotto $\mathrm{D}$, et al. Effects of methylmercury on male reproductive functions in Wistar rats. Reprod Toxicol. 2011;31(4):431-9.

73. Fu Y, Jia FB, Wang J, Song M, Liu SM, Li YF, et al. Effects of sub-chronic aluminum chloride exposure on rat ovaries. Life Sci. 2014;100(1):61-6.

74. Gou YY, Lin S, Que DE, Tayo LL, Lin DY, Chen KC, et al. Estrogenic effects in the influents and effluents of the drinking water treatment plants. Environ Sci Pollut Res Int. 2016;23(9):8518-28.

75. Haghighi KS, Aminian O, FarzanehChavoshi, Bahaedini LS, Soltani S, Najarkolaei F. Relationship between blood lead level and male reproductive hormones in male lead exposed workers of a battery factory: A cross-sectional study. Iran J Reprod Med. 2013;11(8):673-6. 76. Heath JC, Abdelmageed Y, Braden TD, Goyal HO. The effects of chronic ingestion of mercuric chloride on fertility and testosterone levels in male Sprague Dawley rats. J Biomed Biotechnol. 2012;2012:815186.

77. Hosni H, Selim O, Abbas M, Fathy A. Semen quality and reproductive endocrinal function related to blood lead levels in infertile painters. Andrologia. 2013;45(2):120-7. 78. Hu G, Li J, Shan Y, Li X, Zhu Q, Li H, et al. In utero combined di-(2-ethylhexyl) phthalate and diethyl phthalate exposure cumulatively impairs rat fetal Leydig cell development. Toxicology. 2018;395:23-33.

79. Huang Q, Luo L, Alamdar A, Zhang J, Liu L, Tian M, et al. Integrated proteomics and metabolomics analysis of rat testis: Mechanism of arsenic-induced male reproductive toxicity. Sci Rep. 2016;6:32518.

80. Huang X, Zhou Y, Ma J, Wang N, Zhang Z, Ji J, et al. Nitric oxide mediated effects on reproductive toxicity caused by carbon disulfide in male rats. Environ Toxicol Pharmacol. 2012;34(3):679-87.

81. Iavicoli I, Carelli G, Stanek EJ, 3rd, Castellino N, Calabrese EJ. Effects of low doses of dietary lead on puberty onset in female mice. Reprod Toxicol. 2004;19(1):35-41.

82. Jambor T, Lukacova J, Tvrda E, Knazicka Z, Forgacs Z, Lukac N. The Impact of 4Nonylphenol on the Viability and Hormone Production of Mouse Leydig Cells. Folia Biol (Praha). 2016;62(1):34-9.

83. Jarry H, Gamer A, Wuttke W. Effects of 5-day styrene inhalation on serum LH and testosterone levels and on hypothalamic and striatal amino acid neurotransmitter concentrations in male rats. Inhal Toxicol. 2004;16(4):209-15.

84. Kim SH, Nam KH, Hwang KA, Choi KC. Influence of hexabromocyclododecane and 4-nonylphenol on the regulation of cell growth, apoptosis and migration in prostatic cancer cells. Toxicol In Vitro. 2016;32:240-7.

85. Knazicka Z, Lukac N, Forgacs Z, Tvrda E, Lukacova J, Slivkova J, et al. Effects of mercury on the steroidogenesis of human adrenocarcinoma (NCI-H295R) cell line. J Environ Sci Health A Tox Hazard Subst Environ Eng. 2013;48(3):348-53.

86. Kopp TI, Lundqvist J, Petersen RK, Oskarsson A, Kristiansen K, Nellemann C, et al. In vitro screening of inhibition of PPAR-gamma activity as a first step in identification of potential breast carcinogens. Hum Exp Toxicol. 2015;34(11):1106-18.

87. Kumar N, Sharan S, Srivastava S, Roy P. Assessment of estrogenic potential of diethyl phthalate in female reproductive system involving both genomic and non-genomic actions. Reprod Toxicol. 2014;49:12-26.

88. Kumar N, Srivastava S, Roy P. Impact of low molecular weight phthalates in inducing 
reproductive malfunctions in male mice: Special emphasis on Sertoli cell functions. Gen

775 Comp Endocrinol. 2015;215:36-50.

89. Lei HL, Wei HJ, Ho HY, Liao KW, Chien LC. Relationship between risk factors for infertility in women and lead, cadmium, and arsenic blood levels: a cross-sectional study from Taiwan. BMC Public Health. 2015;15:1220.

90. Li CJ, Yeh CY, Chen RY, Tzeng CR, Han BC, Chien LC. Biomonitoring of blood 2015;300:815-22.

91. Li X, Sun Z, Manthari RK, Li M, Guo Q, Wang J. Effect of gestational exposure to arsenic on puberty in offspring female mice. Chemosphere. 2018;202:119-26.

92. Luderer U, Morgan MS, Brodkin CA, Kalman DA, Faustman EM. Reproductive endocrine effects of acute exposure to toluene in men and women. Occup Environ Med. 1999;56(10):657-66.

93. Maloney EK, Waxman DJ. trans-Activation of PPARalpha and PPARgamma by structurally diverse environmental chemicals. Toxicol Appl Pharmacol. 1999;161(2):209-18. 94. Martin MB, Reiter R, Pham T, Avellanet YR, Camara J, Lahm M, et al. Estrogen-like activity of metals in MCF-7 breast cancer cells. Endocrinology. 2003;144(6):2425-36.

95. McGregor AJ, Mason HJ. Chronic occupational lead exposure and testicular endocrine function. Hum Exp Toxicol. 1990;9(6):371-6.

96. Mori N, Sawada N, Iwasaki M, Yamaji T, Goto A, Shimazu T, et al. Circulating sex hormone levels and colorectal cancer risk in Japanese postmenopausal women: The JPHC nested case-control study. Int J Cancer. 2019;145(5):1238-44.

97. Moussa H, Hachfi L, Trimeche M, Najjar MF, Sakly R. Accumulation of mercury and its effects on testicular functions in rats intoxicated orally by methylmercury. Andrologia. 2011;43(1):23-7.

98. Munoz A, Chervona Y, Hall M, Kluz T, Gamble MV, Costa M. Sex-specific patterns and deregulation of endocrine pathways in the gene expression profiles of Bangladeshi adults exposed to arsenic contaminated drinking water. Toxicol Appl Pharmacol. 2015;284(3):3308.

99. Ohno K, Azuma Y, Date K, Nakano S, Kobayashi T, Nagao Y, et al. Evaluation of styrene oligomers eluted from polystyrene for estrogenicity in estrogen receptor binding assay, reporter gene assay, and uterotrophic assay. Food Chem Toxicol. 2003;41(1):131-41. 100. Ohno K, Azuma Y, Nakano S, Kobayashi T, Hirano S, Nobuhara Y, et al. Assessment of styrene oligomers eluted from polystyrene-made food containers for estrogenic effects in in vitro assays. Food Chem Toxicol. 2001;39(12):1233-41.

101. Ohyama KI, Nagai F, Tsuchiya Y. Certain styrene oligomers have proliferative activity on MCF-7 human breast tumor cells and binding affinity for human estrogen receptor. Environ Health Perspect. 2001;109(7):699-703.

102. Okazaki H, Takeda S, Matsuo S, Matsumoto M, Furuta E, Kohro-Ikeda E, et al. Inhibitory modulation of human estrogen receptor alpha and beta activities by dicyclohexyl phthalate in human breast cancer cell lines. J Toxicol Sci. 2017;42(4):417-25.

103. Ono A, Kawashima K, Sekita K, Hirose A, Ogawa Y, Saito M, et al. Toluene inhalation induced epididymal sperm dysfunction in rats. Toxicology. 1999;139(3):193-205. 104. Pant N, Upadhyay G, Pandey S, Mathur N, Saxena DK, Srivastava SP. Lead and cadmium concentration in the seminal plasma of men in the general population: correlation with sperm quality. Reprod Toxicol. 2003;17(4):447-50.

105. Parodi DA, Greenfield M, Evans C, Chichura A, Alpaugh A, Williams J, et al. Alteration of mammary gland development and gene expression by in utero exposure to arsenic. Reprod Toxicol. 2015;54:66-75.

106. Pomatto V, Cottone E, Cocci P, Mozzicafreddo M, Mosconi G, Nelson ER, et al. 
824 Plasticizers used in food-contact materials affect adipogenesis in 3T3-L1 cells. J Steroid 825 Biochem Mol Biol. 2018;178:322-32.

826 107. Ramdhan DH, Kamijima M, Wang D, Ito Y, Naito H, Yanagiba Y, et al. Differential response to trichloroethylene-induced hepatosteatosis in wild-type and PPARalphahumanized mice. Environ Health Perspect. 2010;118(11):1557-63.

108. Rodamilans M, Martinez-Osaba MJ, To-Figueras J, Rivera-Fillat F, Torra M, Perez P, et al. Inhibition of intratesticular testosterone synthesis by inorganic lead. Toxicol Lett. 1988;42(3):285-90.

109. Rodamilans M, Osaba MJ, To-Figueras J, Rivera Fillat F, Marques JM, Perez P, et al. Lead toxicity on endocrine testicular function in an occupationally exposed population. Hum Toxicol. 1988;7(2):125-8.

110. Ronis MJ, Badger TM, Shema SJ, Roberson PK, Shaikh F. Effects on pubertal growth and reproduction in rats exposed to lead perinatally or continuously throughout development. J Toxicol Environ Health A. 1998;53(4):327-41.

111. Selevan SG, Rice DC, Hogan KA, Euling SY, Pfahles-Hutchens A, Bethel J. Blood lead concentration and delayed puberty in girls. N Engl J Med. 2003;348(16):1527-36.

112. Sokol RZ. Reversibility of the toxic effect of lead on the male reproductive axis. Reprod Toxicol. 1989;3(3):175-80.

113. Sokol RZ, Madding CE, Swerdloff RS. Lead toxicity and the hypothalamic-pituitarytesticular axis. Biol Reprod. 1985;33(3):722-8.

114. Specht IO, Toft G, Hougaard KS, Lindh CH, Lenters V, Jonsson BA, et al.

Associations between serum phthalates and biomarkers of reproductive function in 589 adult men. Environ Int. 2014;66:146-56.

115. Sukocheva OA, Yang Y, Gierthy JF, Seegal RF. Methyl mercury influences growthrelated signaling in MCF-7 breast cancer cells. Environ Toxicol. 2005;20(1):32-44.

116. Sun H, Hu C, Jia L, Zhu Y, Zhao H, Shao B, et al. Effects of aluminum exposure on serum sex hormones and androgen receptor expression in male rats. Biol Trace Elem Res. 2011;144(1-3):1050-8.

117. Sun X, Sun H, Yu K, Wang Z, Liu Y, Liu K, et al. Aluminum Chloride Causes the Dysfunction of Testes Through Inhibiting the ATPase Enzyme Activities and Gonadotropin Receptor Expression in Rats. Biol Trace Elem Res. 2018;183(2):296-304.

118. Sun Y, Wang W, Guo Y, Zheng B, Li H, Chen J, et al. High copper levels in follicular fluid affect follicle development in polycystic ovary syndrome patients: Population-based and in vitro studies. Toxicol Appl Pharmacol. 2019;365:101-11.

119. Svensson BG, Nise G, Erfurth EM, Olsson H. Neuroendocrine effects in printing workers exposed to toluene. Br J Ind Med. 1992;49(6):402-8.

120. Takao T, Nanamiya W, Nazarloo HP, Asaba K, Hashimoto K. Possible reproductive toxicity of styrene in peripubertal male mice. Endocr J. 2000;47(3):343-7.

121. Taupeau C, Poupon J, Treton D, Brosse A, Richard Y, Machelon V. Lead reduces messenger RNA and protein levels of cytochrome $\mathrm{p} 450$ aromatase and estrogen receptor beta in human ovarian granulosa cells. Biol Reprod. 2003;68(6):1982-8.

122. Telisman S, Cvitkovic P, Jurasovic J, Pizent A, Gavella M, Rocic B. Semen quality and reproductive endocrine function in relation to biomarkers of lead, cadmium, zinc, and copper in men. Environ Health Perspect. 2000;108(1):45-53.

123. Thoreux-Manlay A, Le Goascogne C, Segretain D, Jegou B, Pinon-Lataillade G. Lead affects steroidogenesis in rat Leydig cells in vivo and in vitro. Toxicology. 1995;103(1):5362.

124. Thoreux-Manlay A, Velez de la Calle JF, Olivier MF, Soufir JC, Masse R, PinonLataillade G. Impairment of testicular endocrine function after lead intoxication in the adult rat. Toxicology. 1995;100(1-3):101-9. 

maternal toluene exposure on testosterone levels in fetal rats. Toxicol Lett. 2009;185(2):79-

87684.

877 126. Wang N, She Y, Zhu Y, Zhao H, Shao B, Sun H, et al. Effects of subchronic aluminum exposure on the reproductive function in female rats. Biol Trace Elem Res. 2012;145(3):382-7.

880 127. Wang YX, Zeng Q, Sun Y, You L, Wang P, Li M, et al. Phthalate exposure in 881 association with serum hormone levels, sperm DNA damage and spermatozoa apoptosis: A cross-sectional study in China. Environ Res. 2016;150:557-65.

883 occupational exposures as a cause of male infertility. Ceylon Med J. 2015;60(2):52-6. 129. Wolff MS, Engel SM, Berkowitz GS, Ye X, Silva MJ, Zhu C, et al. Prenatal phenol and phthalate exposures and birth outcomes. Environ Health Perspect. 2008;116(8):1092-7. 130. Wu JJ, Wang KL, Wang SW, Hwang GS, Mao IF, Chen ML, et al. Differential effects of nonylphenol on testosterone secretion in rat Leydig cells. Toxicology. 2010;268(1-2):1-7. 131. Wu T, Buck GM, Mendola P. Blood lead levels and sexual maturation in U.S. girls: the Third National Health and Nutrition Examination Survey, 1988-1994. Environ Health Perspect. 2003;111(5):737-41.

132. Xu LC, Sun H, Chen JF, Bian Q, Qian J, Song L, et al. Evaluation of androgen receptor transcriptional activities of bisphenol A, octylphenol and nonylphenol in vitro. Toxicology. 2005;216(2-3):197-203.

133. Xu Y, Tokar EJ, Waalkes MP. Arsenic-induced cancer cell phenotype in human breast epithelia is estrogen receptor-independent but involves aromatase activation. Arch Toxicol. 2014;88(2):263-74.

134. Zeng Q, Yi H, Huang L, An Q, Wang H. Reduced testosterone and Ddx3y expression caused by long-term exposure to arsenic and its effect on spermatogenesis in mice. Environ Toxicol Pharmacol. 2018;63:84-91.

135. Zhang X, Wang Y, Zhao Y, Chen X. Experimental study on the estrogen-like effect of mercuric chloride. Biometals. 2008;21(2):143-50.

136. Zhang ZW, Zhi G, Qiao N, Kang ZL, Chen ZL, Hu LM, et al. Copper-Induced Spermatozoa Head Malformation Is Related to Oxidative Damage to Testes in CD-1 Mice. Biol Trace Elem Res. 2016;173(2):427-32.

137. Bay K, Main KM, Toppari J, Skakkebaek NE. Testicular descent: INSL3, testosterone, genes and the intrauterine milieu. Nat Rev Urol. 2011;8(4):187-96.

138. Emmen JM, McLuskey A, Adham IM, Engel W, Verhoef-Post M, Themmen AP, et al. Involvement of insulin-like factor 3 (Insl3) in diethylstilbestrol-induced cryptorchidism. Endocrinology. 2000;141(2):846-9.

139. Klonisch T, Muller-Huesmann H, Riedel M, Kehlen A, Bialek J, Radestock Y, et al. INSL3 in the benign hyperplastic and neoplastic human prostate gland. Int J Oncol. 2005;27(2):307-15.

140. Lague E, Tremblay JJ. Antagonistic effects of testosterone and the endocrine disruptor mono-(2-ethylhexyl) phthalate on INSL3 transcription in Leydig cells. Endocrinology. 2008;149(9):4688-94.

141. Olokpa E, Bolden A, Stewart LV. The Androgen Receptor Regulates PPARgamma Expression and Activity in Human Prostate Cancer Cells. J Cell Physiol. 2016;231(12):266472.

142. Olokpa E, Moss PE, Stewart LV. Crosstalk between the Androgen Receptor and PPAR Gamma Signaling Pathways in the Prostate. PPAR Res. 2017;2017:9456020.

143. Zimmermann S, Steding G, Emmen JM, Brinkmann AO, Nayernia K, Holstein AF, et al. Targeted disruption of the Insl3 gene causes bilateral cryptorchidism. Mol Endocrinol. 
1999;13(5):681-91.

925 144. US EPA. Toxicity Forecasting - ToxCast.

926 2018. [cited 2020 April]; Available from: https://comptox.epa.gov/dashboard.

927 145. Vandenberg LN, Agerstrand M, Beronius A, Beausoleil C, Bergman A, Bero LA, et

928 al. A proposed framework for the systematic review and integrated assessment (SYRINA) of

929 endocrine disrupting chemicals. Environ Health. 2016;15(1):74.

930 146. Sakkiah S, Guo W, Pan B, Kusko R, Tong W, Hong H. Computational prediction

931 models for assessing endocrine disrupting potential of chemicals. J Environ Sci Health C

932 Environ Carcinog Ecotoxicol Rev. 2018;36(4):192-218.

933 147. Fong J-P, Lee F-J, Lu I-S, Uang S-N, Lee C-C. Relationship between urinary

934 concentrations ofdi(2-ethylhexyl) phthalate (DEHP) metabolites andreproductive hormones in

935 polyvinyl chlorideproduction worker. Occup Environ Med. 2015;72:346-53.

936 148. Morgan M, Deoraj A, Felty Q, Roy D. Environmental estrogen-like endocrine

937 disrupting chemicals and breast cancer. Mol Cell Endocrinol. 2017;457:89-102.

938 149. EPA. Bis(2-ethylhexyl) phthalate (DEHP). 1992. [cited 2020 April]; Available from:

939 https://www.epa.gov/sites/production/files/2016-09/documents/bis-2-ethylhexyl-

940 phthalate.pdf.

941 150. IARC. Inorganic and Organic Lead Compounds. IARC Monogr Eval Carcinog Risks

942 Hum. 2006; 87:1-471.

943 151. Shirkhanloo H, Golbabaei F, Hassani H, Eftekhar F, Kian MJ. Occupational Exposure

944 to Mercury: Air Exposure Assessment and Biological Monitoring based on Dispersive Ionic

945 Liquid-Liquid Microextraction. Iran J Public Health. 2014;43(6):793-9.

946 152. US EPA. Nonylphenol (NP) and Nonylphenol Ethoxylates (NPEs) Action Plan. 2010.

947 [cited 2020 April]; Available from: https://www.epa.gov/sites/production/files/2015-

948 09/documents/rin2070-za09_np-npes_action_plan_final_2010-08-09.pdf.

949 153. SCOEL. Recommendation from the Scientific Committee on Occupational Exposure

950 Limits for Copper and its inorganic compounds. 2014.

951 154. EPA. Toluene. 1992. [cited 2020 April]; Available from:

952 https://www.epa.gov/sites/production/files/2016-09/documents/toluene.pdf.

953

954

955

956

957

958

959

960

961

962

963

964

965

966

155. Canadian Centre for Occupational Health and Safety (CCOHS). OSH Answers Fact Sheets - Alzheimer's Disease and Aluminum Exposure. 2019. [cited 2020 April]; Available from: https://www.ccohs.ca/oshanswers/diseases/alzheime.html.

156. Riihimaki V, Aitio A. Occupational exposure to aluminum and its biomonitoring in perspective. Crit Rev Toxicol. 2012;42(10):827-53.

157. Hines CJ, Nilsen Hopf NB, Deddens JA, Calafat AM, Silva MJ, Grote AA, et al.

Urinary phthalate metabolite concentrations among workers in selected industries: a pilot

biomonitoring study. Ann Occup Hyg. 2009;53(1):1-17.

158. EPA. Styrene 1992. [cited 2020 April]; Available from:

https://www.epa.gov/sites/production/files/2016-09/documents/styrene.pdf.

159. IARC. Bisphenol A Diglycidyl Ether. IARC Monogr Eval Carcinog Risks Hum. 1999; 71(Pt 3):1285-9.

160. IARC. Butyl Benzyl Phthalate. IARC Monogr Eval Carcinog Risks Hum. 1999; 73:155-29.

967 161. IARC. Cadmium and Cadmium Compounds. IARC Monogr Eval Carcinog Risks

968 Hum. 1993; 58:119-237.

969 162. Centers for Disease Control and Prevention (CDC). Carbon Disulfide. 2019. [cited

9702020 April]; Available from: https://www.cdc.gov/niosh/topics/carbon-disulfide/default.html.

971 163. European Commission (EC). European Union Risk Assessment Report - Dibutyl

972 phthalate. 2004; 29. 
973 164. US EPA. Phthalates Action Plan. 2012. [cited 2020 April]; Available from:

974 https://www.epa.gov/sites/production/files/2015-

975 09/documents/phthalates_actionplan_revised_2012-03-14.pdf.

976 165. Hines CJ, Hopf NB, Deddens JA, Silva MJ, Calafat AM. Occupational exposure to

977 diisononyl phthalate (DiNP) in polyvinyl chloride processing operations. Int Arch Occup

978 Environ Health. 2012;85(3):317-25.

979 166. Consumer Product Safety Commission of United States (CPSC). Review of Exposure

980 Data and Assessments for Select Dialkyl Ortho-Phthalates. 2010. [cited 2020 April];

981 Available from: https://www.cpsc.gov/s3fs-public/pthalexp.pdf.

982 167. Agency for Toxic Substances and Disease Registry (ATSDR). Case Studies in

983 Environmental Medicine (CSEM) Ethylene Glycol and Propylene Glycol Toxicity. 2007

984 [cited 2020 April]; Available from:

985 https://www.atsdr.cdc.gov/csem/csem.asp?csem=12\&po=6.

986 168. Committee for Recommendation of Occupational Exposure Limits, Azuma K, Endo

987 G, Endo Y, Fukushima T, Hara K, et al. Occupational exposure limits for ethylene glycol

988 monobutyl ether, isoprene, isopropyl acetate and propyleneimine, and classifications on

989 carcinogenicity, occupational sensitizer and reproductive toxicant. J Occup Health.

990 2017;59(4):364-6.

991 169. Faroon, Obaid M, Samuel Keith, L, Smith-Simon, Cassandra, De Rosa, Christopher

992 T, World Health Organization. et al. Polychlorinated biphenyls : human health aspects. World

993 Health Organization. 2003. [cited 2020 April]; Available

994 from: https://apps.who.int/iris/handle/10665/42640.

995 170. Centers for Disease Control and Prevention (CDC). Tetrachloroethylene

996 (Perchloroethylene). 2019. [cited 2020 April]; Available from:

997 https://www.cdc.gov/niosh/topics/tetrachloro/default.html.

998 171. EPA. Phenol. 1992. [cited 2020 April]; Available from:

999 https://www.epa.gov/sites/production/files/2016-09/documents/phenol.pdf.

1000 172. EPA. Trichloroethylene. 1992. [cited 2020 April]; Available from:

1001 https://www.epa.gov/sites/production/files/2016-09/documents/trichloroethylene.pdf.

1002 173. EPA. Xylenes (Mixed Isomers). 1992. [cited 2020 April]; Available from:

1003 https:/www.epa.gov/sites/production/files/2016-09/documents/xylenes.pdf. 